Cogburn. His teaching style was

like no other. He employed a reader, a student who would read aloud a passage from the textbook. Dr. Riley would then lecture his students on the material. You had to be alert if you sat on the front row in Dr. Riley's class. He tended to gesture by swinging his cane, and more than a few toes were stepped on as Riley paced a little too close to the front-row students. But it didn't matter. The man had a lot of wisdom to impart, and he dispensed that wisdom with a keen-though sometimes off-the wall-sense of humor."

Bob was never content merely to teach political science. His passion for politics kept him in the public arena throughout his academic career. He ably served the Arkadelphia community on the board of directors of the chamber of commerce, the city council, as fire commissioner, and as mayor. Long active in Democratic party politics, in 1970, he was elected lieutenant governor of Arkansas. Reelected in 1972, he became governor in January 1975 in the interim following the resignation of Governor Dale Bumpers, who had been elected to the United States Senate, and the inauguration of the new governor, David Pryor.

He then returned to full-time teaching until his fragile health began to fail in 1978. He retired in 1980. That year, the political science department created the Bob Riley Award to recognize an outstanding graduating senior.

For almost a quarter century, Bob charmed and challenged Ouachita students. He transformed his physical disabilities into opportunities for teaching and for closer relationships with his students. In the classroom, as well as on the political stump, he was a legendary raconteur. We remember him with affection and respect for his love of teaching and politics, his patriotism, and his commitment to public service.

Harold F. Bass, Jr. Daniel R. Grant Ouachita Baptist University

\section{Charles M. Tidmarch}

Charles M. Tidmarch, professor of political science at Union College, died at his home on October 29,1993 , after a long and courageous battle with cancer. He was fifty.

Charley was the very model of what a faculty member can be at a small liberal arts college. He was a dedicated teacher, an active and productive scholar, and a superb citizen, taking leadership roles in his department, college, community, and profession. He managed to play all of these roles with a quiet modesty. Many people who were aware of his contributions in one of these roles were completely unaware of his many contributions in other areas.

He was, above all, a dedicated teacher. He taught courses on congressional politics, party politics, urban politics, the mass media, and public policy making. Although skilled in the classroom, perhaps his greatest skill was supervising independent research-both course papers and the senior thesis that is the centerpiece of a Union College education. He taught his students to be daring and resourceful. $\mathrm{He}$ treated them more like colleagues than students, collaborating with some in research projects that were published jointly. He inspired a number of his students to follow his example and become political scientists, and he kept in touch with all of them over the years.

Charley managed to be a very productive scholar. He published some fifteen scholarly articles in some of the leading professional journals in the discipline and presented numerous papers. He did research on congressional elections, legislative committees, rollcall voting, gubernatorial elections, political campaigns, and the mass media. Indeed, he was one of the first political scientists to do systematic research about how newspapers cover congressional campaigns. He started by subscribing to a bunch of newspapers from across the country until he was inundated with data (although precious little about congressional campaigns). At the time of his death he was working on a book entitled The Language of Legislative Life, an analysis of policy discourse in Congress. He was also completing a history of Union's political science department to be published as part of a collection on the occasion of the College's

Bicentennial Celebration in 1995.

He was an active and effective citizen at Union. He chaired the Department of Political Science for five years, was elected as the faculty's representative on the Board of Trustees, was elected by the faculty to serve as its head (chair of the Faculty Executive Committee), and chaired or sat on more committees than we can begin to recount. He took faculty governance seriously, and enjoyed the trust, respect, and affection of colleagues across the campus.

He was equally active outside Union. He was a member of the editorial board of $P S$, a member of the executive committee of $\mathrm{Pi}$ Sigma Alpha and editor of its quarterly newsletter, and a member of the executive council of the Northeastern Political Science Association. An accomplished musician, he played guitar and sang in a rock band known as "Charley $\mathrm{T}$ and the Undergrads." His renditions of "Blue Suede Shoes" and many other rock classics were memorable.

Charles Tidmarch graduated from Moravian College and did his graduate work at Johns Hopkins University, earning his Ph.D. in 1972. He joined Union's faculty in 1970 , moving up through the ranks until he reached full professor in 1986. He spent 1978-79 as a Congressional Fellow of the American Political Science Association, and $1986-87$ as visiting professor of politics at Princeton University.

Charley is survived by his beloved wife, Laura, and two daughters, Alexandra, 17, and Victoria, 11. Mrs. Tidmarch asks that friends send written remembrances of her husband to be included in albums she will assemble for Alexandra and Victoria.

A fund has been established to help provide for the education of his daughters. Contributions may be sent to the Tidmarch Family Scholarship Fund, Department of 
Political Science, Union College, Schenectady, New York 12308.

R. Douglas Arnold

Princeton University

James E. Underwood

Union College

\section{Harold Webb, Jr.}

Harold "Chick" Webb, Jr., professor emeritus at Duquesne University in Pittsburgh, died January 22, 1994, of lymphoma. Dr. Webb, 68 , taught political science at Duquesne for 34 years, specializing in international relations.

He served at one time as associate editor of the "Duquesne Review" and conducted research on the Liberal Party of Great Britain. He wrote articles and gave lectures on Catholic higher education. He was one of three professors offering a team-taught Introduction to Political Science course at Duquesne, and was considered one of the finest teachers at that university.

Webb, a native of Philadelphia, received his bachelor's and master's degrees from the University of Pennsylvania, and his doctorate from Brown University. He spent two years as a Fulbright Scholar in London. He was awarded a Purple Heart for his service with the U.S. Army 14th Armored Division in France during World War II.

Webb suffered a sight impairment due to injuries from that war. His wife, Katherine Kinniry Webb, read books onto tapes for Webb to "read," and read student term papers to him so that Webb could grade them. Webb is survived by his widow; three sons, Robert, Timothy, and Richard; one daughter, Karen A. Webb; a sister, Nancy; and five grandsons.

Pat Dunham

Duquesne University

\section{Frederick L. Zimmermann}

We regret the passing of Frederick L. Zimmermann, a long-time member of the American Political Science Association and of the political science faculty at Hunter College in New York City. Born in Brooklyn, New York, Professor Zimmermann received a B.A. in 1928 and an M.A. in 1930 from Columbia University. He was elected to six one-year terms in the New York State Assembly between 1930 and 1935 . In 1936 he joined the faculty of Hunter College and continued to teach there until his retirement in 1970. From 1960 until 1969, Fred served as chair of the Hunter political science department.

Shortly after his retirement, he left New York City to live in a part of the world that he deeply loved: the Hudson River Valley south of Albany.

During his years at Hunter, Fred's courses in American national government, state government, political parties, and federalism were amongst the most popular given by the political science department. He brought to the classroom not only scholarly understanding but practical knowledge drawn from his years in the New York State Legislature. One unusual feature of Fred's service is that during his first decade or more at Hunter he was the only man in a department composed entirely of women. Founded in 1870, Hunter was a college for women until the late 1960 s when men were first admitted as students at the Park Avenue campus in Manhattan. It apparently was the policy of the college for many decades not to appoint men to the college faculty (though its early presidents were all men).

Fred Zimmermann was one of the nation's leading authorities on American federalism. His particular field of expertise was the interstate compact. At a time when such agreements were relatively rare, Fred was a forceful advocate of their use by the states as a means to resolve common problems. In 1951 and again ten years later, he published books for the Council of State Governments (in collabora- tion with his friend Mitchell Wendell) on interstate compacts. In addition, he wrote many scholarly articles (again often with Mitchell Wendell) on interstate compacts that appeared in such journals as State Government, Columbia Law Review, Georgetown Law Journal, Western Political Science Quarterly, and the American Political Science Review.

In addition to his teaching and writing, Fred was called upon by many governmental agencies to provide knowledge and advice about specific intergovernmental problems. For more than three decades, Fred served as a consultant to such organizations as the New York State Legislature, the United States Department of State, the Atlantic States Marine Fisheries Commission, the Interstate Commission on the Delaware Basin, the Port of New York Authority, and the Association of Attorneys General. Fred was one of the founders of the Council of State Governments and played an important part in initiating and drafting a large number of interstate compacts, including: the Atlantic State Marine Fisheries Compact (1941), the Gulf States Marine Fisheries Compact (1946), the Interstate Civil Defense Compact (1950), the Tennessee River Basin Pollution Abatement Compact (1957), the Great Lakes Basin Compact (1957), and the Detainer Compact (1957).

But those of us who served with Fred in the Department of Political Science will remember him as a kind, gentle, caring friend and associate. As a new member of the department in the mid-1960s, I recall his special concern for the junior members of the faculty. His knowledge and encouragement played an important part in providing a foundation for my career as a college professor. He will long be remembered by me, by his other former colleagues, and by his many friends.

Walter E. Volkomer Hunter College 